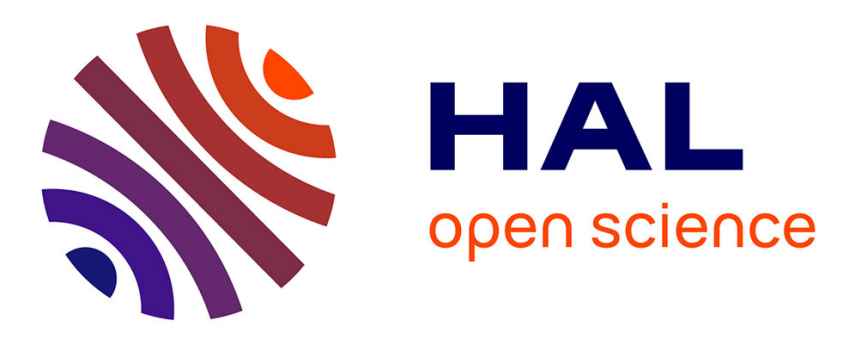

\title{
Ethanol exerts anti-inflammatory effects in human adipose tissue
}

\author{
Anne Wandler, Jens M. Bruun, Maria P. Nielsen, Bjørn Richelsen
}

\section{To cite this version:}

Anne Wandler, Jens M. Bruun, Maria P. Nielsen, Bjørn Richelsen. Ethanol exerts anti-inflammatory effects in human adipose tissue. Molecular and Cellular Endocrinology, 2008, 296 (1-2), pp.26. 10.1016/j.mce.2008.09.006 . hal-00532075

\section{HAL Id: hal-00532075 \\ https://hal.science/hal-00532075}

Submitted on 4 Nov 2010

HAL is a multi-disciplinary open access archive for the deposit and dissemination of scientific research documents, whether they are published or not. The documents may come from teaching and research institutions in France or abroad, or from public or private research centers.
L'archive ouverte pluridisciplinaire HAL, est destinée au dépôt et à la diffusion de documents scientifiques de niveau recherche, publiés ou non, émanant des établissements d'enseignement et de recherche français ou étrangers, des laboratoires publics ou privés. 


\section{Accepted Manuscript}

Title: Ethanol exerts anti-inflammatory effects in human adipose tissue in vitro

Authors: Anne Wandler, Jens M. Bruun, Maria P. Nielsen, Bjørn Richelsen

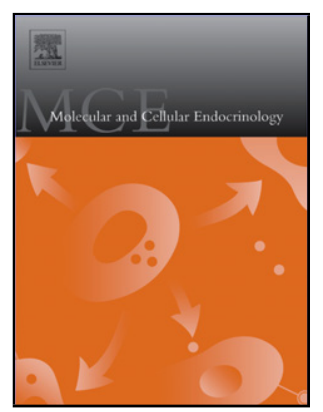

PII:

S0303-7207(08)00403-6

DOI: doi:10.1016/j.mce.2008.09.006

Reference: MCE 6975

To appear in: Molecular and Cellular Endocrinology

Received date: 3-6-2008

Revised date: $17-8-2008$

Accepted date: 7-9-2008

Please cite this article as: Wandler, A., Bruun, J.M., Nielsen, M.P., Richelsen, B., Ethanol exerts anti-inflammatory effects in human adipose tissue in vitro., Molecular and Cellular Endocrinology (2008), doi:10.1016/j.mce.2008.09.006

This is a PDF file of an unedited manuscript that has been accepted for publication. As a service to our customers we are providing this early version of the manuscript. The manuscript will undergo copyediting, typesetting, and review of the resulting proof before it is published in its final form. Please note that during the production process errors may be discovered which could affect the content, and all legal disclaimers that apply to the journal pertain. 
Ethanol exerts anti-inflammatory effects in human adipose tissue in vitro.

Anne Wandler, Jens M. Bruun, Maria P. Nielsen, Bjørn Richelsen.

Department of Endocrinology and Metabolism C, Aarhus University Hospital, Aarhus Sygehus, Tage Hansensgade, Aarhus C, Denmark

Running title: Anti-inflammatory effects of ethanol in human adipose tissue

Corresponding author:

Jens M. Bruun, MD.

Department of Endocrinology and Metabolism C

Aarhus University Hospital

Aarhus Sygehus

Tage Hansensgade 2

DK-8000 Aarhus C

Denmark

Phone: +4589497683

Fax: +4589497649

E-mail: Jens.Bruun@ki.au.dk 
Keywords: Ethanol, Adipokines, Inflammation, Adipose tissue (human), Macrophages.

\begin{abstract}
$\underline{\text { Abstract }}$
Moderate alcohol consumption is suggested to be associated with reduced inflammation and morbidity. Human adipose tissue (AT) and obesity is characterised by low-grade inflammation, why the present study wanted to investigate the effects of ethanol on inflammation in human AT in vitro. Subcutaneous human AT was incubated with ethanol [11mM - 88mM] under non- or LPSstimulated $[50 \mathrm{mg} / \mathrm{mL}]$ conditions. Protein and mRNA levels of adiponectin, IL-6, IL-8, TNF- $\alpha$, MCP-1, and CD68 were assessed using ELISA and Real-Time RT-PCR, respectively.

Non-stimulated, ethanol incubations up to $24 \mathrm{~h}$ increased adiponectin release and mRNA expression $(p<0.01)$ and decreased IL-6 release in both short term $[1.5 \mathrm{~h}](\mathrm{p}<0.05)$ and long term $[24 \mathrm{~h}](\mathrm{p}<0.01)$ incubations. Ethanol decreased LPS-stimulated IL-6, IL-8, TNF- $\alpha$, and MCP-1 dose-dependently (all $\mathrm{p}<0.01)$. Ethanol decreased CD68 mRNA ( $<<0.001)$, which correlated with the investigated adipokines $(\mathrm{p}<0.05)$ but not adiponectin $(\mathrm{p}>0.05)$.

In conclusion, ethanol exerts anti-inflammatory effects in human AT, suggesting that ethanol may attenuate whole-body inflammation.
\end{abstract}




\section{Introduction}

Human adipose tissue (AT) produces and releases a number of bio-active proteins, collectively referred to as adipokines (Trayhurn and Wood, 2004), of which several are reported to be increased in overweight and obese subjects [e.g. interleukin (IL)-6 (Bastard et al., 2000), IL-8 (Bruun et al., 2003b), Tumour Necrosis Factor (TNF)- $\alpha$ (Hotamisligil et al., 1995), and Monocyte Chemoattractant Protein (MCP)-1 (Bruun et al., 2005)]. Interestingly, obesity is associated with a state of low-grade inflammation reported to precede metabolic diseases such as insulin resistance, type 2 diabetes, atherosclerosis and cardiovascular disease (Despres and Lemieux, 2006; Dandona et al., 2004). The actual link between obesity and low-grade inflammation is still unknown but may involve an increase in the production and release of pro-inflammatory adipokines [e.g. IL-6, IL-8, TNF- $\alpha$, MCP-1] combined with a decrease in the anti-inflammatory adipokine, adiponectin (Arita et al., 1999), which may be related to the recently demonstrated increased infiltration of macrophages in AT from obese patients (Weisberg et al., 2003; Bruun et al., 2005; Cancello et al., 2005).

Alcohol is known to exert numerous effects in humans of which the deleterious ones caused by excess consumption are well-known and strongly associated with excess morbidity and mortality [reviewed in (Klatsky, 2007)]. During the last decades several epidemiological studies have reported associations between low to moderate alcohol consumption and reduced cardiovascular morbidity and mortality (Gronbaek, 2002; Klatsky and Udaltsova, 2007). Even though causality remains to be elucidated, several in vivo studies have reported beneficial effects of various combinations of ethanol [e.g. wine, beer, liquor] on especially circulating levels of High Density Lipoprotein cholesterol (HDL) (Sacanella et al., 2002; Wannamethee et al., 2003; Badia et al., 2004; Sierksma et al., 2004). Another possible link between moderate alcohol consumption and the reduced risk of developing metabolic disease is suggested to be mediated through alcohol induced 
anti-inflammatory effects via changes in classical [e.g. hs-CRP, fibrinogen] (Sierksma et al., 2002; Estruch et al., 2004) as well as newer risk markers [e.g. adiponectin, MCP-1, VCAM-1, ICAM-1] (Sierksma et al., 2004; Estruch et al., 2004). Supporting this hypothesis, several in vitro studies is demonstrating anti-inflammatory effects of ethanol in various cell-types such as spleen cell-cultures and macrophages (Friedman, 1998; Szabo et al., 1999; Saeed et al., 2004), blood monocytes (Szabo et al., 1999), and endothelial cells (Saeed et al., 2004).

Since human AT have an inflammatory potential and whole body (low-grade) inflammation in obese individuals seems to precede the metabolic diseases outlined above (Dandona et al., 2004), the aim of the present study was to investigate the effects of ethanol on the expression and secretion of various adipokines [e.g. adiponectin, IL-6, IL-8, TNF- $\alpha$, and MCP-1] and the macrophage specific marker CD68 in human AT in vitro.

\section{Materials and methods}

\subsection{Whole adipose tissue cultures}

Subcutaneous AT from the abdominal and gluteal AT-depots was obtained from 34 normal to overweight but otherwise healthy individuals [29 females and 5 males; mean age: $38 \pm 12$ yrs.] undergoing liposuction for cosmetic reasons [mean body mass index (BMI): $25.4 \pm 4.9 \mathrm{~kg} / \mathrm{m}^{2}$ ]. None of the subjects received any medication known to influence AT metabolism.

After removal the AT was kept under sterile conditions and transported to the laboratory within 60 min. At the laboratory, all subsequent procedures were carried out under a laminar airflow hood. The AT was washed several times in sterile saline. As previously described, the AT was minced into fragments of less than $10 \mathrm{mg}$ and a total of $500 \mathrm{mg}$ of was placed in $50 \mathrm{~mL}$ plastic tubes containing 5mL medium 199 supplemented with Penicillin/Streptomycin (100 IU/mL), 
antipain/leupeptin $(20 \mu \mathrm{L} / \mathrm{mL})$ and $1 \mathrm{nM}$ insulin $(1 \mu \mathrm{L} / 100 \mathrm{~mL}$ medium) (Bruun et al., 2001). The AT fragments were pre-incubated in a humidified incubator $\left(37^{\circ} \mathrm{C}\right)$ at an atmosphere of $5 \% \mathrm{CO}_{2}$. The pre-incubation time was adjusted in order to make the total incubation time comparable between the various experiments. After pre-incubation, AT fragments were incubated for 1.5, 6, 12, or $24 \mathrm{~h}$ in medium 199 with different concentrations of ethanol [11 mM, $22 \mathrm{mM}, 44 \mathrm{mM}$, or 88 $\mathrm{mM}$ ]. Incubations were performed with or without lipopolysaccharide [LPS; up to $50 \mathrm{mg} / \mathrm{L}$ ] in order to activate an inflammatory response in the AT. All experiments are carried out as duplicates in renewed medium 199. The culture medium obtained from the different incubations was kept at $20{ }^{\circ} \mathrm{C}$ until analyses were performed. The AT was snap frozen in liquid nitrogen and kept at $-80{ }^{\circ} \mathrm{C}$ for later RNA extractions.

\subsection{Determination of adipokine secretion and $m R N A$ levels}

Protein secretion to the culture medium was assessed using human enzyme-linked immunosorbent assays (ELISA; adiponectin; B-Bridge, AH diagnostics AS, Denmark and IL-6, IL-8, TNF- $\alpha$, and MCP-1; DuoSet, R\&D Systems Europe Ltd., UK). Samples were diluted to be within the assay range. The IL-6 assay had an intra-assay coefficient of variation of $5.5 \%$. The IL-8 assay had an intra-assay coefficient of variation of $7.9 \%$. The TNF- $\alpha$ assay had an intra-assay coefficient of variation of $6.7 \%$. The MCP-1 assay had an intra-assay coefficient of variation of $8.1 \%$.

For mRNA determination the following oligonucleotide primer pairs were used. adiponectin: 5'CATGACCAGGAAACCACGACT3'; ～5'TGAATGCTGAGCGGTAT3', IL-6: 5'AAATGCCAGCCTGCTGACGAAG3'; 5'AACAACAATCTGAGGTGCCCATGCTAC3'， IL-8: 5'TTGGCAGCCTTCCTGATTTC3'; $\quad$ 5'AACTTCTCCACAACCCTCTG3', $\quad$ TNF- $\alpha$ : 5'CGAGTGACAAGCCTGtAGC3'; $\quad$ 5'GGTGTGGGTGAGGAGCACAT3', $\quad$ MCP-1:

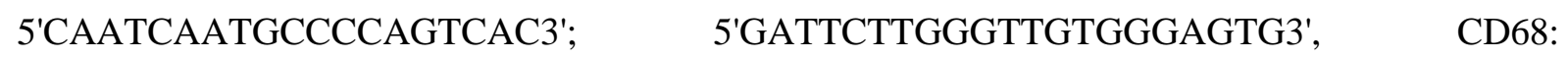


5'CTACATGGCGGTGGAGTACAA3'; 5'ATGATGAGAGGCAGCAAGATGG3', and $\beta$-actin: 5'ACGGGGTCACCCACACTGTGC 3'; 5'CTAGAAGCATTTGCGGTGGACGATG3'. RNA was isolated from $250 \mathrm{mg}$ of AT using the TriZol Reagent (Invitrogen, Carlsbad, CA). RNA was quantified by measuring absorbancy at 260 and $280 \mathrm{~nm}$. The integrity of the RNA was checked by visual inspection of the two ribosomal RNAs, $18 \mathrm{~S}$ and $28 \mathrm{~S}$, on an agarose gel. RNA was reversely transcribed with RT and random hexamer primers at $23{ }^{\circ} \mathrm{C}$ for 10 minutes, $42{ }^{\circ} \mathrm{C}$ for 60 minutes, and $95{ }^{\circ} \mathrm{C}$ for 10 minutes according to the manufacturer's instructions (GeneAmp RNA PCR kit, PerkinElmer Life and Analytical Sciences, Boston, MA). Then $2 \mu 1$ of each RT reaction was amplified in PCR-mastermix containing the specific primers, Hot Star Taq DNA polymerase, and SYBR-Green PCR buffer. All samples were determined as duplicates. Real-time quantification of target gene [adiponectin, IL-6, IL-8, TNF- $\alpha$, MCP-1, CD68] relative to housekeeping gene [ $\beta$-actin] was performed using a SYBR-Green real-time PCR assay and an iCycler PCR machine (Bio-Rad, Hercules, CA). In brief, samples were incubated in separate tubes for initial denaturation at $95{ }^{\circ} \mathrm{C}$ for 10 minutes, followed by 40 PCR amplification cycles. Each cycle consisted of 30 seconds at 95 ${ }^{\circ} \mathrm{C}, 30$ seconds at $57{ }^{\circ} \mathrm{C}$ and extension for 60 seconds at $74{ }^{\circ} \mathrm{C}$. During final extension increasing fluorescence was measured in real time. Data was obtained as threshold cycle values $(\mathrm{Ct}=$ the cycle number at which fluorescence reached 10 times the SD of the background fluorescence). Relative gene expression of target gene to $\beta$-actin was calculated as described in the User Bulletin No. 2, 1997 from Perkin Elmer Life and Analytical Sciences (Perkin Elmer Cetus, Norwalk CT, USA).

\subsection{Statistical analysis}

The SigmaStat 2.03 statistical packet (SPSS, Chicago, IL., USA) was used for the calculations. Normality was tested using the Kolmogorov-Smirnov test. A paired Students $t$-test or appropriate non-parametric statistics was applied when comparing mean differences between control/LPS and 
ethanol/LPS+ethanol incubations. To determine the relationship between the mRNA expression of CD68 and the investigated adipokines bivariate correlations with a Pearson correlation coefficient $\left(r_{p}\right)$ was used. Results are presented as mean \pm s.e.m. Threshold for significance was set at $p<0.05$.

\subsection{Ethics}

Informed, written consent was obtained from all subjects and experiments were performed in accordance with the Helsinki II Declaration. The study was approved by the Ethical Committees of Aarhus.

\section{Results}

\subsection{Effect of ethanol on adiponectin in human AT}

In the non-stimulated experiments (without LPS), ethanol incubation for $1.5 \mathrm{~h}[11 \mathrm{mM}]$ was found to increase adiponectin mRNA expression by up to 2.5 -fold $(\mathrm{p}<0.05$, data not shown). After incubation for $24 \mathrm{~h}$, adiponectin release was significantly increased by all ethanol concentrations by up to $33 \%$ (p<0.001, Fig. 1A) and adiponectin mRNA expression was increased by up to 2-fold at ethanol concentrations of $44 \mathrm{mM}(\mathrm{p}<0.05)$ and $88 \mathrm{mM}(\mathrm{p}<0.01)$, respectively (Fig. 1B).

Incubation with LPS significantly reduced adiponectin mRNA expression by $76 \%(\mathrm{p}<0.05)$ but addition of ethanol at the same time was not able to counteract this LPS-induced inhibition of adiponectin mRNA expression (data not shown).

\subsection{Effects of ethanol on IL-6 in human AT}

In the non-stimulated (without LPS) time-course experiments, ethanol was found to induce a short lived decrease in IL-6 already after $1.5 \mathrm{~h}$ (p<0.05, Fig. 2). Hereafter, the release of IL-6 returned to 
initial levels the next 6-12h after which a sustained decrease in the release of IL-6 was observed ( $<<0.05$, Fig. 2). The inhibitory short term effects were found to be comparable for all four different ethanol concentrations, whereas the long term inhibitory effects on IL-6 release were found to be affected by ethanol in a dose-dependent manner (Fig. 2).

Incubation for $24 \mathrm{~h}$ with LPS $[50 \mathrm{mg} / \mathrm{L}]$ resulted in a 4 -fold increase $(p<0.001$, Fig. 3$)$ in the release of IL-6. Ethanol reduced the LPS-induced release of IL-6 in a dose-dependent manner with a maximal decrease of $\sim 30 \%$ at an ethanol concentration of $88 \mathrm{mM}(\mathrm{p}<0.01$, Fig. 3). A similar trend was observed at the gene expression level, however, only an ethanol concentration of $88 \mathrm{mM}$ was found to reduce IL-6 mRNA expression by $36 \%$ ( $\mathrm{p}<0.05$, data not shown).

\subsection{Effects of ethanol on IL-8, TNF $\alpha$, and MCP-1 in human AT}

In the non-stimulated (without LPS) incubations, ethanol had no short term effects on IL-8 but was after incubation for $24 \mathrm{~h}$ found to decrease IL- 8 release by $17 \%$ at an ethanol concentration of $11 \mathrm{mM}(\mathrm{p}<0.05)$ and by $23 \%$ at an alcohol concentration of $88 \mathrm{mM}(\mathrm{p}<0.01$, data not shown $)$.

LPS $[50 \mathrm{mg} / \mathrm{L}]$ was found to induce a 4-fold increase in the release of IL-8 ( $p<0.001$, Fig. 4A). Ethanol induced a dose-dependent decrease in the LPS-induced IL-8 release by $\sim 30 \%$ at an ethanol concentration of $88 \mathrm{mM}$ ( $\mathrm{p}<0.05$, Fig. 4A). Incubation with LPS significantly increased IL-8 mRNA expression by 9 -fold $(\mathrm{p}<0.001)$ but addition of ethanol was not able to counteract this LPS-induced increase in IL-8 mRNA expression (data not shown).

Ethanol was without effects on TNF- $\alpha$ release under non-stimulated (without LPS) conditions even after incubations up to $24 \mathrm{~h}$.

LPS $[50 \mathrm{mg} / \mathrm{L}]$ was found induce a robust 20 -fold increase in TNF- $\alpha$ release $(p<0.001$, Fig. 4B) after incubation for $24 \mathrm{~h}$. Ethanol was found to decrease the release of TNF- $\alpha$ in a dose-dependent 
manner reaching a maximal inhibition of $\sim 28 \%$ at an ethanol concentration of $88 \mathrm{mM}(\mathrm{p}<0.01$, Fig. 4B). Incubation with LPS significantly increased TNF- $\alpha$ mRNA expression by 8 -fold $(\mathrm{p}<0.001)$ but addition of ethanol was not able to counteract this LPS-induced increase in TNF- $\alpha$ mRNA expression (data not shown).

Ethanol was without effects on MCP-1 release under non-stimulated (without LPS) conditions in incubation up to $24 \mathrm{~h}$. Incubation with LPS $[50 \mathrm{mg} / \mathrm{L}]$ for $24 \mathrm{~h}$ was found to increase MCP-1 release by 4 -fold ( $<<0.001$, Fig. 4C). Ethanol was found to decrease the LPS-induced release of MCP-1 in a dose-dependent manner reaching a maximal inhibition of $\sim 39 \%$ at an ethanol concentration of $88 \mathrm{mM}$ (p<0.01, Fig. 4C). Incubation with LPS significantly increased IL-8 mRNA expression by 4fold $(\mathrm{p}<0.001)$ but addition of ethanol was not able to counteract this LPS-induced increase in IL-8 mRNA expression (data not shown).

\subsection{CD68 in relation to ethanol, LPS, and adipokines in human AT}

No correlation was found between CD68 and the investigated adipokines under non-stimulated (without LPS) conditions in incubations up to $24 \mathrm{~h}$. Ethanol alone was without effects on CD68 mRNA expression under the same non-stimulated conditions in incubations up to $24 \mathrm{~h}$.

In the LPS-stimulated [50mg/L] incubations [24h] CD68 mRNA expression correlated with IL-6 $(\mathrm{p}<0.001)$, IL-8 $(\mathrm{p}<0.05)$, TNF- $\alpha(\mathrm{p}<0.01)$, and MCP-1 $(\mathrm{p}<0.05)$ but not with adiponectin $(\mathrm{p}>0.05)$ (Table 1). In addition, LPS was found induce a 2-fold increase in CD68 mRNA expression ( $\mathrm{p}<0.05)$ and ethanol $[88 \mathrm{mM}]$ was found to decrease CD68 mRNA expression by $\sim 50 \%$ (p<0.001, data not shown).

\section{Discussion}


The present paper is to our knowledge the first to report that ethanol exerts general and significant anti-inflammatory effects in whole human AT in vitro, by inducing an increase in adiponectin and a parallel decrease in IL-6, IL-8, TNF- $\alpha$, and MCP-1. Interestingly, incubation with ethanol induced a time-dependent IL-6 response with a significant short-term [1.5h] decrease, a plateau phase for 6$12 \mathrm{~h}$ where IL-6 release returned to initial control values, after which a sustained and significant long-term [>24h] decrease was observed (Fig. 2). Previous studies have found IL-6 release and mRNA expression to display a biphasic response upon various stimuli in human visceral AT cultures (Fain et al., 2005) and 3T3-L1 adipocytes (Fasshauer et al., 2003) supporting the observed findings on IL-6. The molecular pathways involved is suggested to via the receptor complex nuclear factor- $\kappa \mathrm{B}(\mathrm{NF}-\kappa \mathrm{B})$, since acute or short-term [1.5h] ethanol treatment is reported to decrease IL-6 release from human isolated and LPS-stimulated monocytes via transient decrease in NF- $\kappa$ activity (Mandrekar et al., 1997) and similarly, short-term [2-4h] incubation with specific inhibitors of the NF- $\kappa \mathrm{B}$ pathway is reported to decrease IL- 6 release from human visceral AT cultures (Fain et al., 2005).

Alcohol (ethanol) intake is in observational studies found to exert a $\mathrm{J}$-shaped pattern in relation to mortality with an increase in mortality in abstainers, a decrease in mortality in light to moderate drinkers primarily due to a reduction in cardiovascular disease, followed by a dose-dependent increase in mortality in heavy drinkers [ $>40 \mathrm{~g}$ ethanol/day] (Klatsky and Udaltsova, 2007). The background for this pattern is still obscure, however, an increasing number of human studies report a similar J-shaped pattern in relation to various inflammatory markers (Sacanella et al., 2002; Wannamethee et al., 2003; Imhof et al., 2004), suggesting that inflammation may be involved in the observed J-shaped relationship between ethanol and metabolic disease. This is of particular interest, since low-grade inflammation is reported to precede metabolic diseases such as insulin resistance, type 2 diabetes, atherosclerosis and cardiovascular disease (Despres and Lemieux, 2006; Dandona 
et al., 2004). These observational studies are supported by recent rodent studies in which treatment with chronic and high concentrations of ethanol induce insulin resistance (Onishi et al., 2003; Kang et al., 2007), paralleled by an increase in AT-macrophage infiltration and a subsequent increase in AT-inflammation [e.g. increase in IL-6, TNF- $\alpha$, MCP-1 and a decrease in adiponectin] (Kang et al., 2007). In line with the abovementioned rodent studies, recent human intervention studies have shown that moderate alcohol intake is able to decrease inflammation via an increase plasma levels of adiponectin by 10-15\% (Sierksma et al., 2004; Beulens et al., 2007), which is in agreement with our in vitro findings. Moreover, moderate alcohol consumption is reported to improve insulin sensitivity in relatively insulin resistant subjects, an effect that may be mediated via the stimulatory effect of alcohol on adiponectin (Sierksma et al., 2004; Thamer et al., 2004). Thus, in addition to weight loss (Yang et al., 2001; Madsen et al., 2008) and treatment with the antidiabetic drugs, the thiazolidinediones (Maeda et al., 2001), ethanol seems to be able to up-regulate endogenous adiponectin production in humans.

Adiponectin is rather specifically expressed in mature adipocytes but whole AT cultures as used in the present study consists of several other cell-types including inflammatory cells [e.g. monocytes, macrophages], known to infiltrate the AT is relation to the size and topographical localisation of the AT (Weisberg et al., 2003; Bruun et al., 2005; Cancello et al., 2005). Several studies have found inverse interactions between adiponectin and adipokines such as IL-6 and TNF- $\alpha$ (Yokota et al., 2000; Bruun et al., 2003a; Suganami et al., 2005). The short term [1.5h] ethanol-induced upregulation of adiponectin may be mediated directly via effects on the adipocytes per se. However, the observed correlation between CD68 and the pro-inflammatory adipokines [IL-6, IL-8, TNF- $\alpha$, MCP-1], but not the anti-inflammatory adiponectin, confirms previous reports that the SV-fraction of the AT is the primary source of the inflammatory adipokines (Fain et al., 2004; Bruun et al., 2005) and suggests that the observed long term [24h] increase in adiponectin release and mRNA 
expression may be mediated indirectly via paracrine loops in the AT involving especially TNF- $\alpha$ and IL-6, since these pro-inflammatory proteins was found to be down-regulated in parallel. In response to the robust LPS-induced stimulation of IL-6, IL-8, TNF- $\alpha$, and MCP-1 in the human AT incubations, ethanol exerted a significant and dose-dependent inhibition of all of the investigated adipokines. Although this finding is new in relation to AT incubations, it is essentially in line with several previous in vitro studies performed in human isolated monocytes (Szabo et al., 1995; Szabo et al., 1996; Szabo et al., 1999). LPS is a potent pro-inflammatory agent via an activation of the toll-like receptor4 (TLR4), which is reported to act as a central receptor probably mediating some of the anti-inflammatory effects induced by ethanol in vitro (Pruett and Pruett, 2006; Dai and Pruett, 2006). In addition to modulate TLR4 activity, ethanol is also reported to decrease the activity of NF-kB in vitro (Szabo et al., 1999; Saeed et al., 2004; Klatsky and Udaltsova, 2007). The general decrease in inflammatory markers as found in the present study is probably caused by an alcohol-induced decrease in the activity in the NF- $\mathrm{KB}$ system since activation of this system is known to induce the expression of adipokines in human AT as well as to induce preadipocyte proliferation (Lacasa et al., 2007). However, since adiponectin is reported to reduce the activity of the NF- $\mathrm{KB}$ system (Ouchi et al., 2000), it remains to be elucidated whether the alcohol-induced decrease in IL-6, IL-8, TNF- $\alpha$, and MCP-1 found in the present study is related directly to a decrease in NF- $\kappa B$ activity or an adiponectin induced decrease in NF- $\mathrm{BB}$ activity is also involved.

The concordant findings in human AT and human monocytes is probably related to the observed infiltration and activity of inflammatory cell-types such as monocytes and macrophages in human AT (Weisberg et al., 2003; Fain et al., 2004; Bruun et al., 2005). The increase in AT-resident macrophages is associated with adiposity as well as a state of AT-inflammation, potentially reversible through weight loss (Cancello et al., 2005; Bruun et al., 2006). In line with these 
findings, we found robust correlations between CD68 and IL-6, IL-8, TNF- $\alpha$, and MCP-1 but not adiponectin in the LPS-incubations. Even though the number of macrophages in the present incubations must be considered as constant ethanol significantly reduced mRNA expression of the macrophage surrogate marker CD68, suggesting that ethanol may reduce the inflammatory potential of the macrophages already present in the AT incubations and thereby supporting the overall antiinflammatory findings in the present manuscript. The ethanol-concentrations used in the present incubations range from $11 \mathrm{mM}$ to $88 \mathrm{mM}$, which is comparable to the concentrations used in previous in vitro studies (Szabo et al., 1995; Szabo et al., 1999) and known to be associated with a cell viability of $\sim 90 \%$ in vitro (Friedman, 1998). In vivo, in humans, an ethanol concentration of $88 \mathrm{mM}$ may be lethal. The intake of $\sim 24 \mathrm{~g}$ (females) and $\sim 36 \mathrm{~g}$ (males) of ethanol will within $30 \mathrm{~min}$ result in a peak circulating ethanol-concentration of $\sim 11 \mathrm{mM}$ and up to $44 \mathrm{mM}$ will result in various degrees of intoxication, however, since ethanol consumption in humans is associated with a prompt degradation in the liver, it is difficult to extrapolate from the in vitro concentrations used in the present study to the actual ethanol concentration in the AT in vivo. In the present study, already low concentrations of ethanol $[11 \mathrm{mM}]$ was found to decrease LPS-stimulated IL-6, IL-8, TNF- $\alpha$, and MCP-1, and increase the anti-inflammatory adipokine adiponectin. The observed relationship between low concentrations of ethanol and a general decrease in inflammation is supported by other studies in which the anti-inflammatory adipokine, IL-10, was increased using similar ethanol concentration (Mandrekar et al., 1996; Szabo et al., 1996), high concentrations of ethanol oppositely reduced adiponectin mRNA expression in (rodent) epididymal AT (Kang et al., 2007), and recently human in vivo studies found low to moderate alcohol consumption to increase circulating adiponectin levels (Sierksma et al., 2004; Englund et al., 2006).

In conclusion, ethanol was found to exert significant anti-inflammatory effects in a time- and dosedependent manner in human AT fragments in vitro. Even though excess ethanol consumption in 
vivo by far exceeds the beneficial effects of low to moderate consumption as reported in several epidemiological studies, the findings presented may have clinical implications since they support previous in vivo findings that ethanol (in low to moderate concentrations) may be beneficial attenuating whole body low-grade inflammation which is a characteristic feature in patients with obesity.

\section{Acknowledgements}

We greatly appreciate the expert technical assistance of Lenette Pedersen and Pia Hornbek.

The study was supported by the Novo Nordic Foundation, The Danish Medical Research Council, and The Food Study Group/The Danish Ministry of Food, Agriculture and Fisheries.

Conflicts of interest: the authors have nothing to declare.

\section{References}

Arita, Y., Kihara, S., Ouchi, N., Takahashi, M., Maeda, K., Miyagawa, J., Hotta, K., Shimomura, I., Nakamura, T., Miyaoka, K., Kuriyama, H., Nishida, M., Yamashita, S., Okubo, K., Matsubara, K., Muraguchi, M., Ohmoto, Y., Funahashi, T., Matsuzawa, Y., 1999. Paradoxical decrease of an adipose-specific protein, adiponectin, in obesity. Biochem. Biophys. Res. Commun. 257, 79-83.

Badia, E., Sacanella, E., Fernandez-Sola, J., Nicolas, J.M., Antunez, E., Rotilio, D., de, G.G., Urbano-Marquez, A., Estruch, R., 2004. Decreased tumor necrosis factor-induced adhesion of human monocytes to endothelial cells after moderate alcohol consumption. Am. J. Clin. Nutr. 80, 225-230. 
Bastard, J.P., Jardel, C., Bruckert, E., Blondy, P., Capeau, J., Laville, M., Vidal, H., Hainque, B., 2000. Elevated levels of interleukin 6 are reduced in serum and subcutaneous adipose tissue of obese women after weight loss. J. Clin. Endocrinol. Metab. 85, 3338-3342.

Beulens, J.W., van Loon, L.J., Kok, F.J., Pelsers, M., Bobbert, T., Spranger, J., Helander, A., Hendriks, H.F., 2007. The effect of moderate alcohol consumption on adiponectin oligomers and muscle oxidative capacity: a human intervention study. Diabetologia 50, 1388-1392.

Bruun, J.M., Helge, J.W., Richelsen, B., Stallknecht, B., 2006. Diet and exercise reduce low-grade inflammation and macrophage infiltration in adipose tissue but not in skeletal muscle in severely obese subjects. Am. J. Physiol Endocrinol. Metab 290, E961-E967.

Bruun, J.M., Lihn, A.S., Pedersen, S.B., Richelsen, B., 2005. Monocyte Chemoattractant Protein-1 Release is Higher in Visceral than Subcutaneous Human Adipose Tissue (AT). Implication of Macrophages resident in the AT. J. Clin. Endocrinol. Metab 90, 2282-2289.

Bruun, J.M., Lihn, A.S., Verdich, C., Pedersen, S.B., Toubro, S., Astrup, A., Richelsen, B., $2003 a$. Regulation of adiponectin by adipose tissue-derived cytokines: in vivo and in vitro investigations in humans. Am. J. Physiol Endocrinol. Metab 285, E527-E533.

Bruun, J.M., Pedersen, S.B., Richelsen, B., 2001. Regulation of Interleukin 8 Production and Gene Expression in Human Adipose Tissue in Vitro. J. Clin. Endocrinol. Metab. 86, 1267-1273.

Bruun, J.M., Verdich, C., Toubro, S., Astrup, A., Richelsen, B., 2003b. Association between measures of insulin sensitivity and circulating levels of interleukin-8, interleukin-6 and 
tumor necrosis factor-alpha. Effect of weight loss in obese men. Eur. J. Endocrinol. 148, $535-542$.

Cancello, R., Henegar, C., Viguerie, N., Taleb, S., Poitou, C., Rouault, C., Coupaye, M., Pelloux, V., Hugol, D., Bouillot, J.L., Bouloumie, A., Barbatelli, G., Cinti, S., Svensson, P.A., Barsh, G.S., Zucker, J.D., Basdevant, A., Langin, D., Clement, K., 2005. Reduction of macrophage infiltration and chemoattractant gene expression changes in white adipose tissue of morbidly obese subjects after surgery-induced weight loss. Diabetes 54, 2277-2286.

Dai, Q. and Pruett, S.B., 2006. Ethanol suppresses LPS-induced Toll-like receptor 4 clustering, reorganization of the actin cytoskeleton, and associated TNF-alpha production. Alcohol Clin. Exp. Res. 30, 1436-1444.

Dandona, P., Aljada, A., Bandyopadhyay, A., 2004. Inflammation: the link between insulin resistance, obesity and diabetes. Trends Immunol. 25, 4-7.

Despres, J.P. and Lemieux, I., 2006. Abdominal obesity and metabolic syndrome. Nature 444, 881887.

Englund, O.L., Brohall, G., Behre, C.J., Schmidt, C., Fagerberg, B., 2006. Alcohol consumption in relation to metabolic regulation, inflammation, and adiponectin in 64-year-old Caucasian women: a population-based study with a focus on impaired glucose regulation. Diabetes Care 29, 908-913. 
Estruch, R., Sacanella, E., Badia, E., Antunez, E., Nicolas, J.M., Fernandez-Sola, J., Rotilio, D., de, G.G., Rubin, E., Urbano-Marquez, A., 2004. Different effects of red wine and gin consumption on inflammatory biomarkers of atherosclerosis: a prospective randomized crossover trial. Effects of wine on inflammatory markers. Atherosclerosis 175, 117-123.

Fain, J.N., Bahouth, S.W., Madan, A.K., 2005. Involvement of multiple signaling pathways in the post-bariatric induction of IL-6 and IL-8 mRNA and release in human visceral adipose tissue. Biochem. Pharmacol. 69, 1315-1324.

Fain, J.N., Madan, A.K., Hiler, M.L., Cheema, P., Bahouth, S.W., 2004. Comparison of the release of adipokines by adipose tissue, adipose tissue matrix, and adipocytes from visceral and subcutaneous abdominal adipose tissues of obese humans. Endocrinology 145, 2273-2282.

Fasshauer, M., Klein, J., Lossner, U., Paschke, R., 2003. Interleukin (IL)-6 mRNA Expression is Stimulated by Insulin, Isoproterenol, Tumour Necrosis Factor Alpha, Growth Hormone, and IL-6 in 3T3-L1 Adipocytes. Horm. Metab Res. 35, 147-152.

Friedman, H., 1998. Alcohol effects on cytokine responses by immunocytes. Alcohol Clin. Exp. Res. 22, 184S-187S.

Gronbaek, M., 2002. Alcohol, type of alcohol, and all-cause and coronary heart disease mortality. Ann. N. Y. Acad Sci 957, 16-20. 
Hotamisligil, G.S., Arner, P., Caro, J.F., Atkinson, R.L., Spiegelman, B.M., 1995. Increased adipose tissue expression of tumor necrosis factor-alpha in human obesity and insulin resistance. J. Clin. Invest. 95, 2409-2415.

Imhof, A., Woodward, M., Doering, A., Helbecque, N., Loewel, H., Amouyel, P., Lowe, G.D., Koenig, W., 2004. Overall alcohol intake, beer, wine, and systemic markers of inflammation in western Europe: results from three MONICA samples (Augsburg, Glasgow, Lille). Eur. Heart J. 25, 2092-2100.

Kang, L., Sebastian, B.M., Pritchard, M.T., Pratt, B.T., Previs, S.F., Nagy, L.E., 2007. Chronic ethanol-induced insulin resistance is associated with macrophage infiltration into adipose tissue and altered expression of adipocytokines. Alcohol Clin. Exp. Res. 31, 1581-1588.

Klatsky, A.L., 2007. Alcohol, cardiovascular diseases and diabetes mellitus. Pharmacol. Res. 55, 237-247.

Klatsky, A.L. and Udaltsova, N., 2007. Alcohol drinking and total mortality risk. Ann. Epidemiol. 17, S63-S67.

Lacasa, D., Taleb, S., Keophiphath, M., Miranville, A., Clement, K., 2007. Macrophage-secreted factors impair human adipogenesis: involvement of proinflammatory state in preadipocytes. Endocrinology 148, 868-877.

Madsen, E.L., Rissanen, A., Bruun, J.M., Skogstrand, K., Tonstad, S., Hougaard, D.M., Richelsen, B., 2008. Weight loss larger than $10 \%$ is needed for general improvement of levels of 
circulating adiponectin and markers of inflammation in obese subjects: a 3-year weight loss study. Eur. J. Endocrinol. 158, 179-187.

Maeda, N., Takahashi, M., Funahashi, T., Kihara, S., Nishizawa, H., Kishida, K., Nagaretani, H., Matsuda, M., Komuro, R., Ouchi, N., Kuriyama, H., Hotta, K., Nakamura, T., Shimomura, I., Matsuzawa, Y., 2001. PPARgamma ligands increase expression and plasma concentrations of adiponectin, an adipose-derived protein. Diabetes 50, 2094-2099.

Mandrekar, P., Catalano, D., Girouard, L., Szabo, G., 1996. Human monocyte IL-10 production is increased by acute ethanol treatment. Cytokine 8, 567-577.

Mandrekar, P., Catalano, D., Szabo, G., 1997. Alcohol-induced regulation of nuclear regulatory factor-kappa beta in human monocytes. Alcohol Clin. Exp. Res. 21, 988-994.

Onishi, Y., Honda, M., Ogihara, T., Sakoda, H., Anai, M., Fujishiro, M., Ono, H., Shojima, N., Fukushima, Y., Inukai, K., Katagiri, H., Kikuchi, M., Oka, Y., Asano, T., 2003. Ethanol feeding induces insulin resistance with enhanced PI 3-kinase activation. Biochem. Biophys. Res. Commun. 303, 788-794.

Ouchi, N., Kihara, S., Arita, Y., Okamoto, Y., Maeda, K., Kuriyama, H., Hotta, K., Nishida, M., Takahashi, M., Muraguchi, M., Ohmoto, Y., Nakamura, T., Yamashita, S., Funahashi, T., Matsuzawa, Y., 2000. Adiponectin, an adipocyte-derived plasma protein, inhibits endothelial NF-kappaB signaling through a cAMP-dependent pathway. Circulation 102, 1296-1301. 
Pruett, B.S. and Pruett, S.B., 2006. An explanation for the paradoxical induction and suppression of an acute phase response by ethanol. Alcohol 39, 105-110.

Sacanella, E., Badia, E., Nicolas, J.M., Fernandez-Sola, J., Antunez, E., Urbano-Marquez, A., Estruch, R., 2002. Differential effects of moderate or heavy alcohol consumption on circulating adhesion molecule levels. Thromb. Haemost. 88, 52-55.

Saeed, R.W., Varma, S., Peng, T., Tracey, K.J., Sherry, B., Metz, C.N., 2004. Ethanol blocks leukocyte recruitment and endothelial cell activation in vivo and in vitro. J. Immunol. 173, 6376-6383.

Sierksma, A., Patel, H., Ouchi, N., Kihara, S., Funahashi, T., Heine, R.J., Grobbee, D.E., Kluft, C., Hendriks, H.F., 2004. Effect of moderate alcohol consumption on adiponectin, tumor necrosis factor-alpha, and insulin sensitivity. Diabetes Care 27, 184-189.

Sierksma, A., van der Gaag, M.S., Kluft, C., Hendriks, H.F., 2002. Moderate alcohol consumption reduces plasma C-reactive protein and fibrinogen levels; a randomized, diet-controlled intervention study. Eur. J. Clin. Nutr. 56, 1130-1136.

Suganami, T., Nishida, J., Ogawa, Y., 2005. A paracrine loop between adipocytes and macrophages aggravates inflammatory changes: role of free fatty acids and tumor necrosis factor alpha. Arterioscler. Thromb. Vasc. Biol. 25, 2062-2068. 
Szabo, G., Chavan, S., Mandrekar, P., Catalano, D., 1999. Acute alcohol consumption attenuates interleukin-8 (IL-8) and monocyte chemoattractant peptide-1 (MCP-1) induction in response to ex vivo stimulation. J. Clin. Immunol. 19, 67-76.

Szabo, G., Mandrekar, P., Catalano, D., 1995. Inhibition of superantigen-induced $\mathrm{T}$ cell proliferation and monocyte IL-1 beta, TNF-alpha, and IL-6 production by acute ethanol treatment. J. Leukoc. Biol. 58, 342-350.

Szabo, G., Mandrekar, P., Girouard, L., Catalano, D., 1996. Regulation of human monocyte functions by acute ethanol treatment: decreased tumor necrosis factor-alpha, interleukin-1 beta and elevated interleukin-10, and transforming growth factor-beta production. Alcohol Clin. Exp. Res. 20, 900-907.

Thamer, C., Haap, M., Fritsche, A., Haering, H., Stumvoll, M., 2004. Relationship between moderate alcohol consumption and adiponectin and insulin sensitivity in a large heterogeneous population. Diabetes Care 27, 1240.

Trayhurn, P. and Wood, I.S., 2004. Adipokines: inflammation and the pleiotropic role of white adipose tissue. Br. J. Nutr. 92, 347-355.

Wannamethee, S.G., Lowe, G.D., Shaper, G., Whincup, P.H., Rumley, A., Walker, M., Lennon, L., 2003. The effects of different alcoholic drinks on lipids, insulin and haemostatic and inflammatory markers in older men. Thromb. Haemost. 90, 1080-1087. 
Weisberg, S.P., McCann, D., Desai, M., Rosenbaum, M., Leibel, R.L., Ferrante, A.W., Jr., 2003. Obesity is associated with macrophage accumulation in adipose tissue. J. Clin. Invest 112, 1796-1808.

Yang, W.S., Lee, W.J., Funahashi, T., Tanaka, S., Matsuzawa, Y., Chao, C.L., Chen, C.L., Tai, T.Y., Chuang, L.M., 2001. Weight reduction increases plasma levels of an adipose-derived anti-inflammatory protein, adiponectin. J. Clin. Endocrinol. Metab. 86, 3815-3819.

Yokota, T., Oritani, K., Takahashi, I., Ishikawa, J., Matsuyama, A., Ouchi, N., Kihara, S., Funahashi, T., Tenner, A.J., Tomiyama, Y., Matsuzawa, Y., 2000. Adiponectin, a new member of the family of soluble defense collagens, negatively regulates the growth of myelomonocytic progenitors and the functions of macrophages. Blood 96, 1723-1732. 
Legends to figures.

\section{Figure 1}

Effects of ethanol on adiponectin in human adipose tissue

Adiponectin release (Fig. 1A) and mRNA expression (Fig. 1B) was assessed after 24h in nonstimulated adipose tissue incubations with increasing ethanol concentrations $[11 \mathrm{mM}-88 \mathrm{mM}]$.

Data represent mean values \pm s.e.m. $(\mathrm{N}=7)$, with protein concentrations in $[\mu \mathrm{g} / \mathrm{L}]$ and mRNA control values set at $100 .{ }^{*} \mathrm{p}<0.05, * * \mathrm{p}<0.01$, and $* * * \mathrm{p}<0.001$ as compared to control values.

\section{Figure 2}

Effects of ethanol on IL-6 in non-stimulated human adipose tissue.

The effects of increasing ethanol concentrations [closed circle $11 \mathrm{mM}$, open circle $22 \mathrm{mM}$, closed triangle $44 \mathrm{mM}$, open triangle $88 \mathrm{mM}$ ] on IL-6 release was investigated in non-stimulated adipose tissue incubated up to $24 \mathrm{~h}$.

Data represent mean values \pm s.e.m., with control values set at $100(\mathrm{~N}=8)$. $* \mathrm{p}<0.05$ and $* * \mathrm{p}<0.01$ as compared to control values.

\section{Figure 3}

Effects of ethanol on IL-6 in LPS-stimulated human adipose tissue.

The effects of increasing ethanol concentrations [11 mM - $88 \mathrm{mM}]$ on IL-6 release was investigated in LPS-stimulated [50mg/L] adipose tissue incubated for $24 \mathrm{~h}$.

Data represent mean values \pm s.e.m. $(\mathrm{N}=9) .{ }^{*} \mathrm{p}<0.05$ and $* * \mathrm{p}<0.01$ as compared to control values.

\section{Figure 4}

Effects of ethanol on IL-8, TNF- $\alpha$, and MCP-1 in LPS-stimulated human adipose tissue. 
The effects of increasing ethanol concentrations [11 mM - $88 \mathrm{mM}]$ on (A) IL-8, (B) TNF- $\alpha$, and (C) MCP-1 release was investigated in LPS-stimulated [50mg/L] adipose tissue incubated for $24 \mathrm{~h}$.

Data represent mean values \pm s.e.m. $(\mathrm{N}=9) .{ }^{*} \mathrm{p}<0.05$ and $* * \mathrm{p}<0.01$ as compared to control values. 
Table 1

Correlation between CD68 and adipokines in LPS-stimulated AT-incubations in vitro $(\mathrm{N}=15)$.

\section{CD68 mRNA}

Adiponectin mRNA

$r_{p}=0.09(p>0.05)$

IL-6 mRNA

$\mathrm{r}_{\mathrm{p}}=0.81(\mathrm{p}<0.001)$

IL-8 mRNA

$\mathrm{r}_{\mathrm{p}}=0.52(\mathrm{p}<0.05)$

TNF- $\alpha$ mRNA

$\mathrm{r}_{\mathrm{p}}=0.76(\mathrm{p}<0.01)$

MCP-1 mRNA

$r_{p}=0.64(p=0.01)$ 


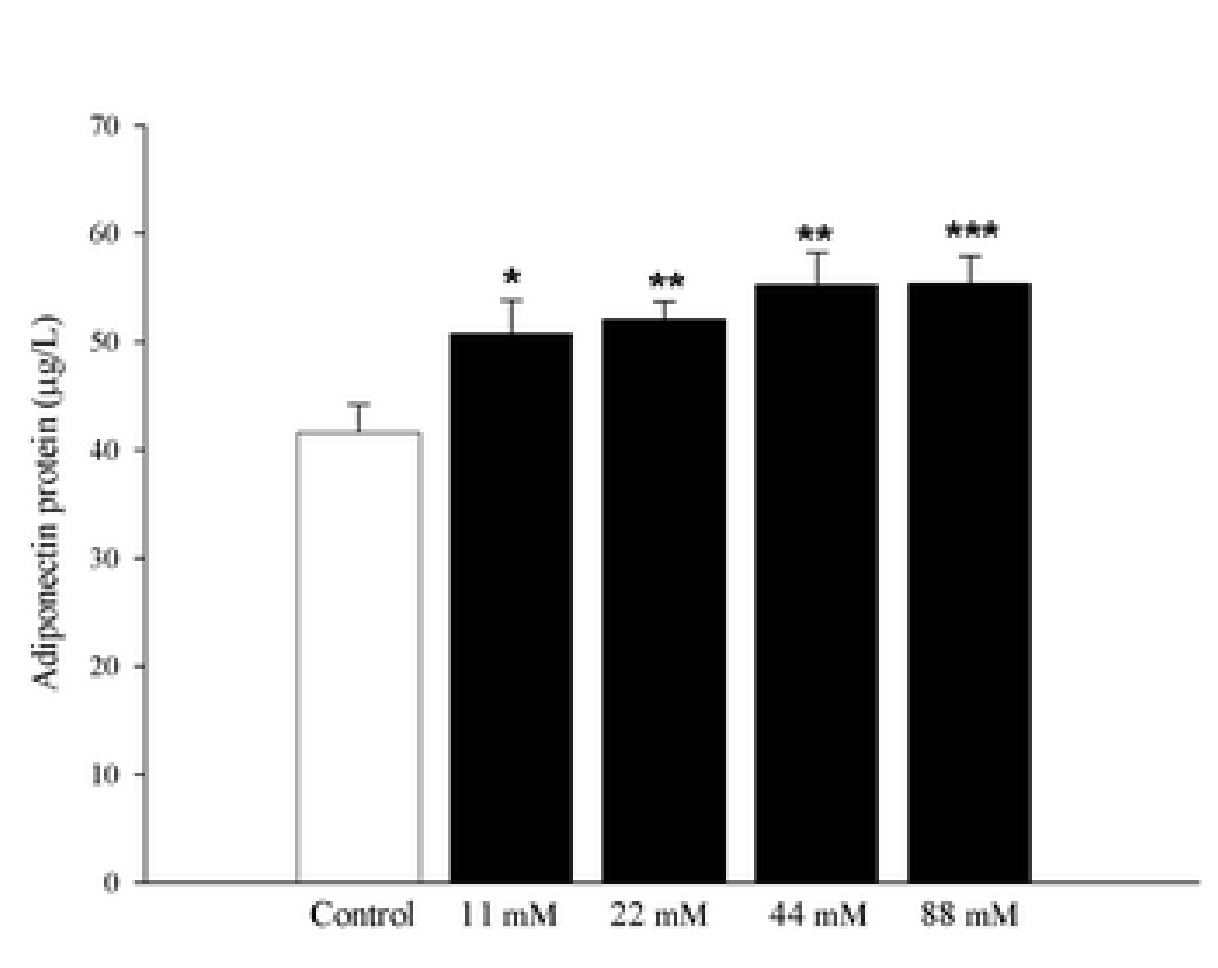

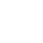

.

\section{Fig. 1A}

!II 


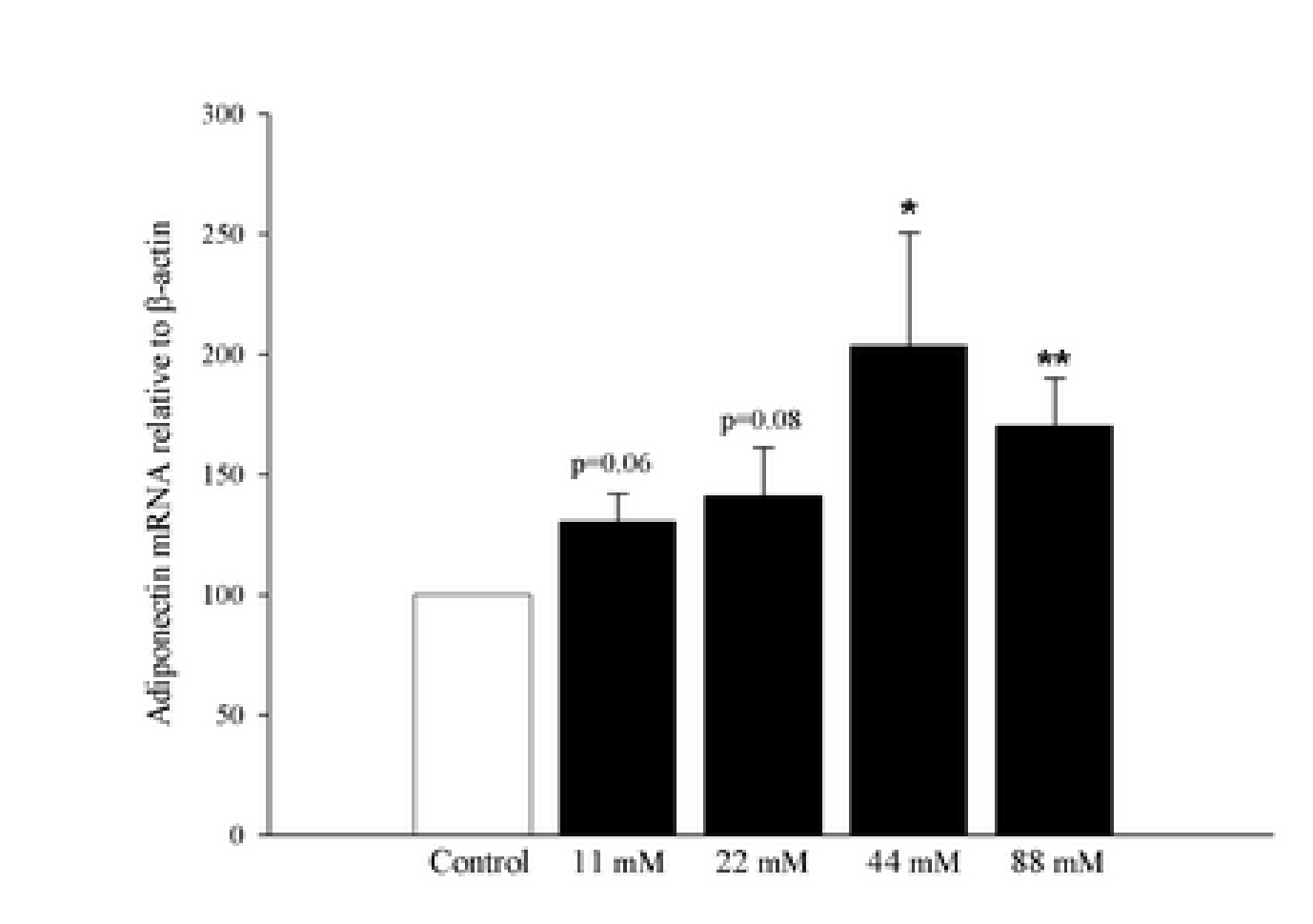

\section{Fig. 1B}

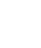

.

W

(1)

(a)




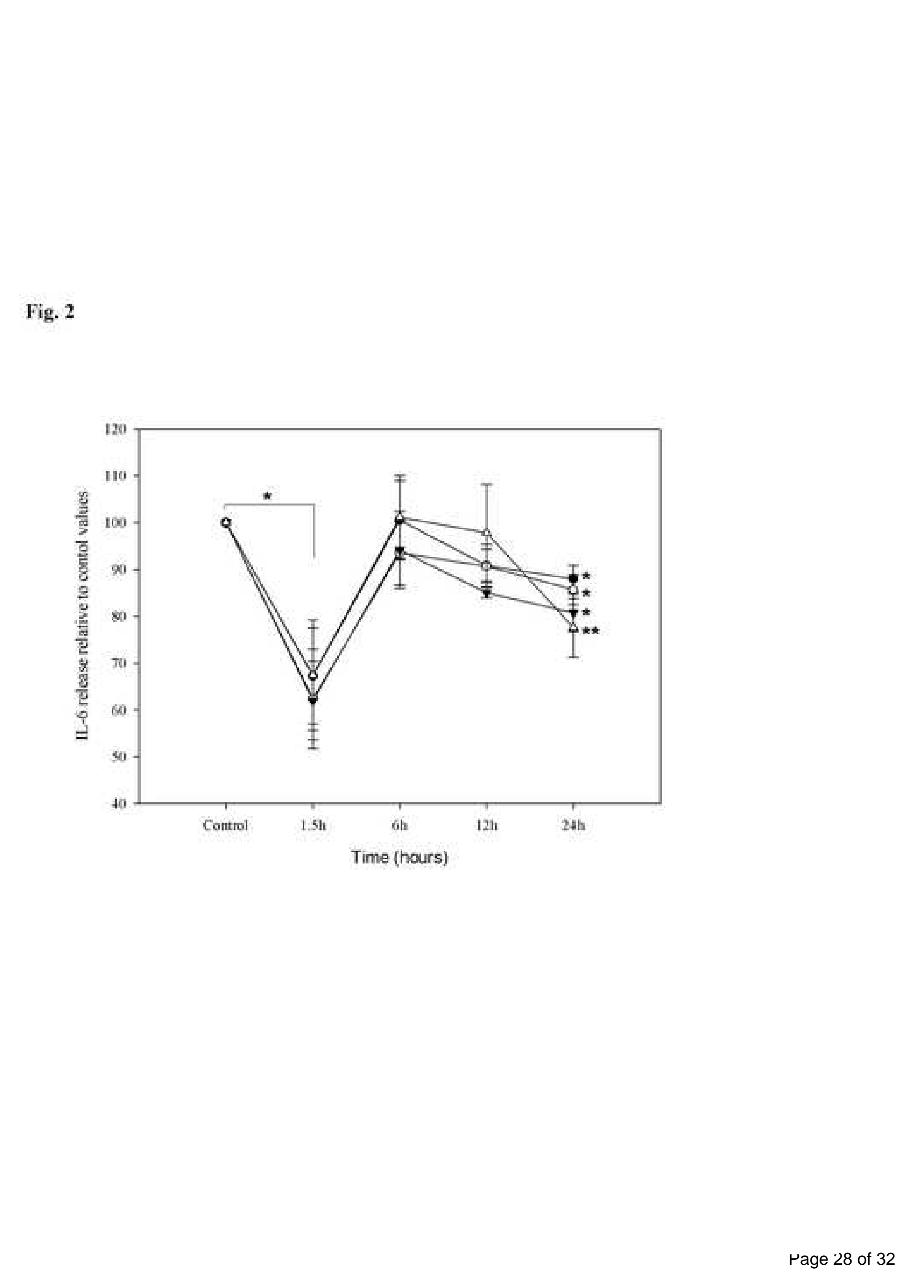

rage 28 of 32

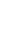

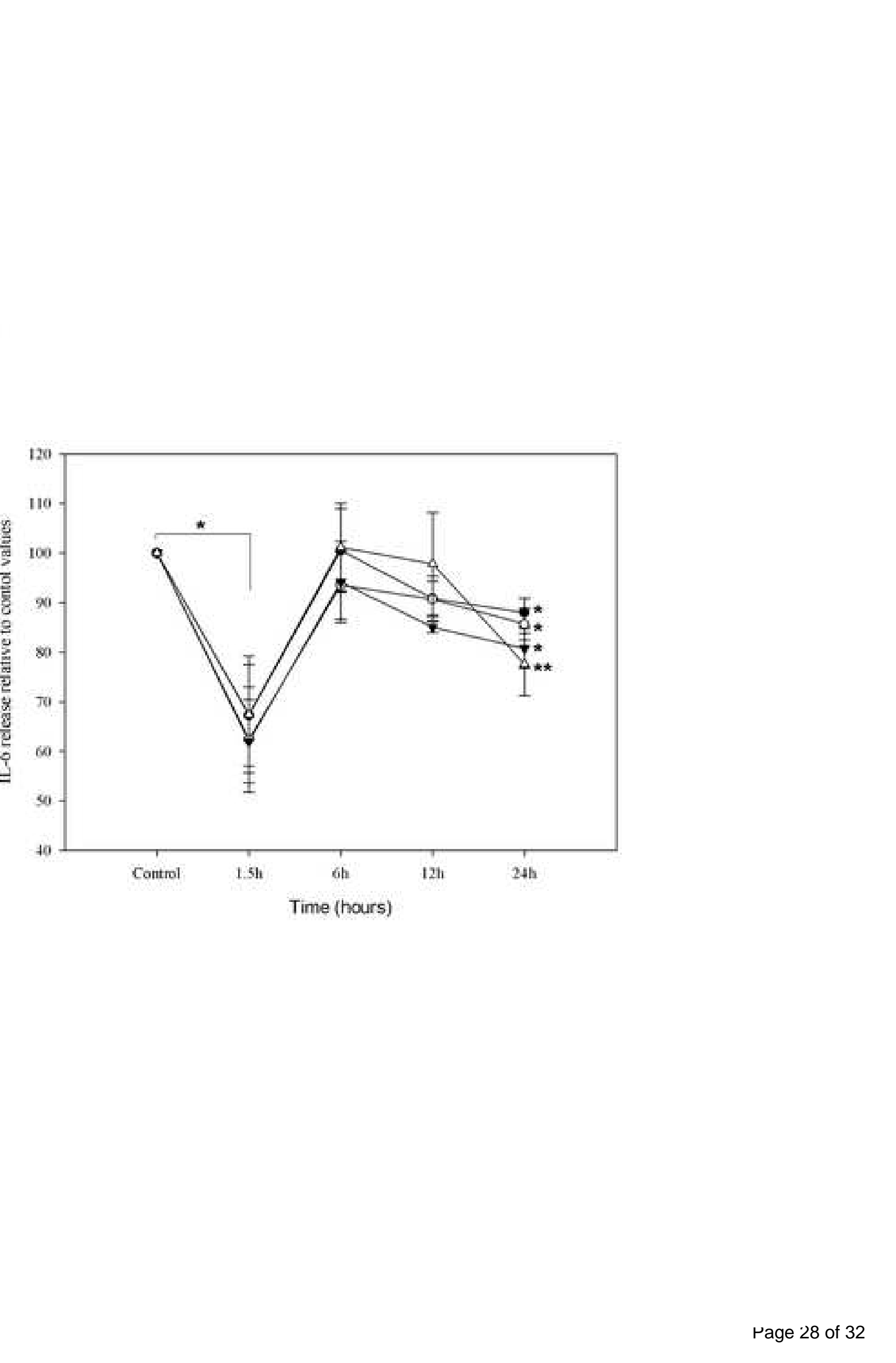

\section{Fig. 2 \\ Fig. 2}




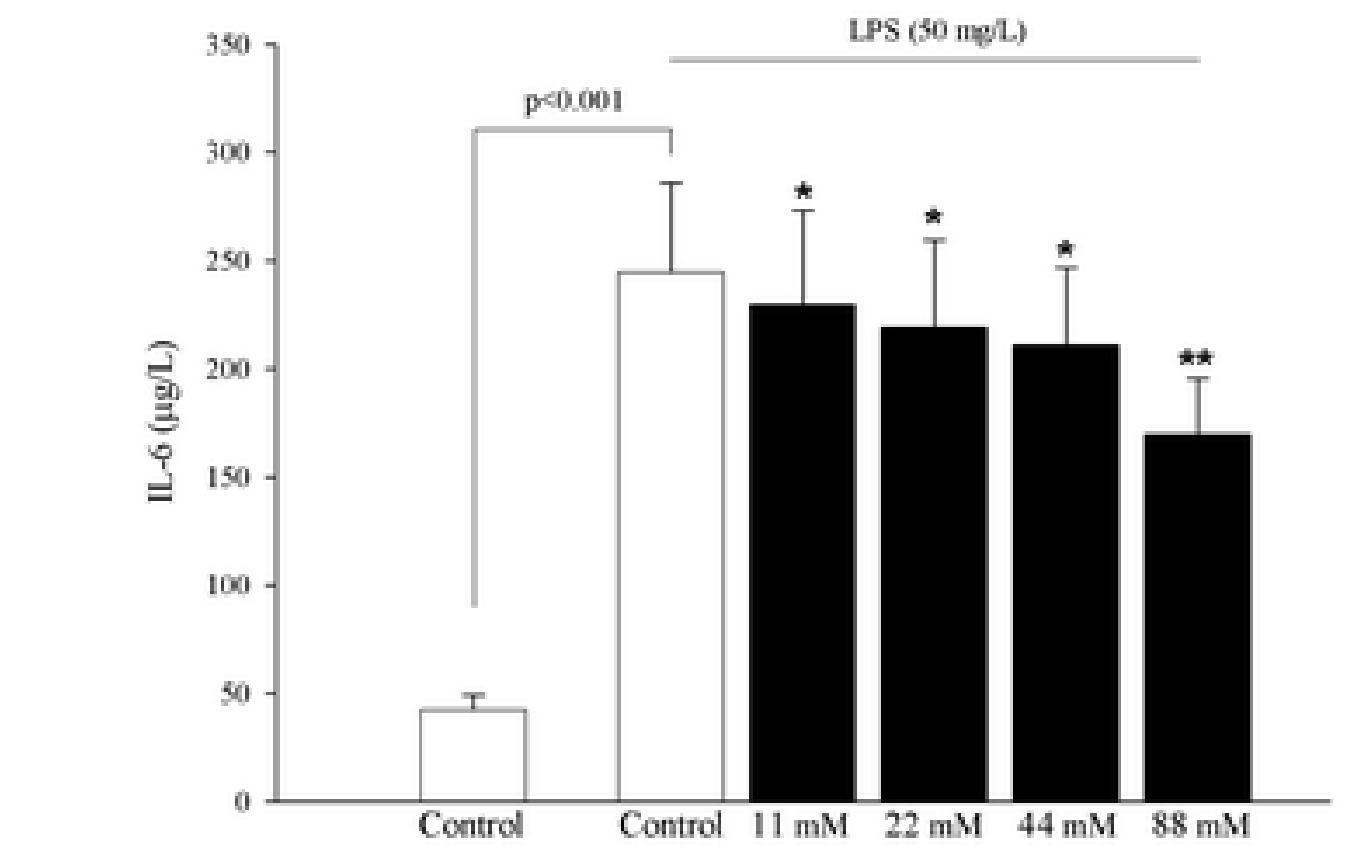

\section{Fig. 3

(1)


Fig. $4 \mathrm{~A}$
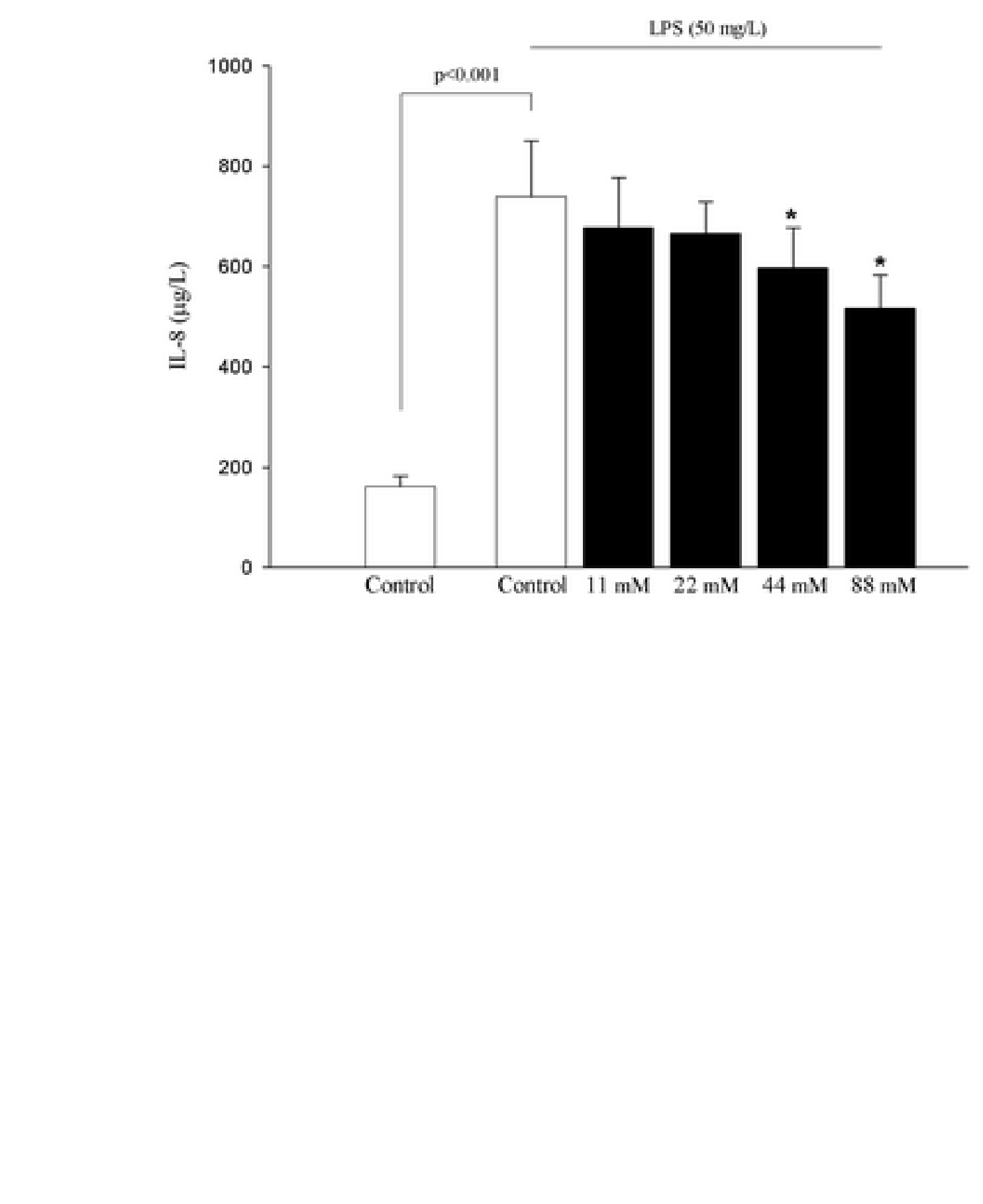

\section{Fig.}


Fig. 4B

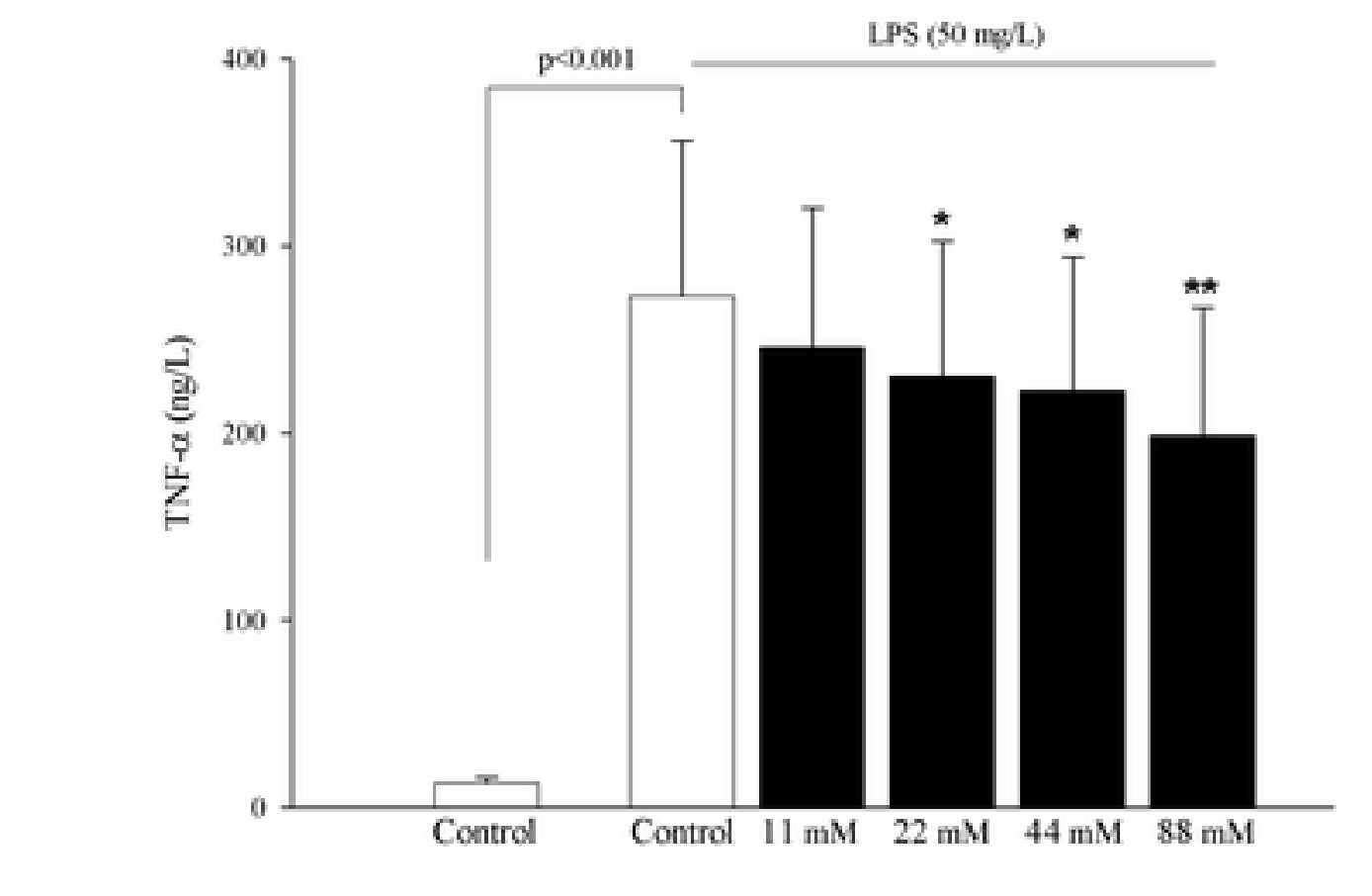

.

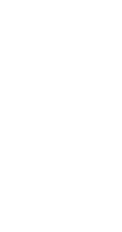

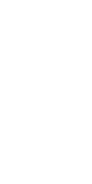

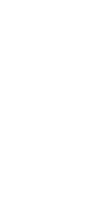

(1)

D.

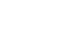


m

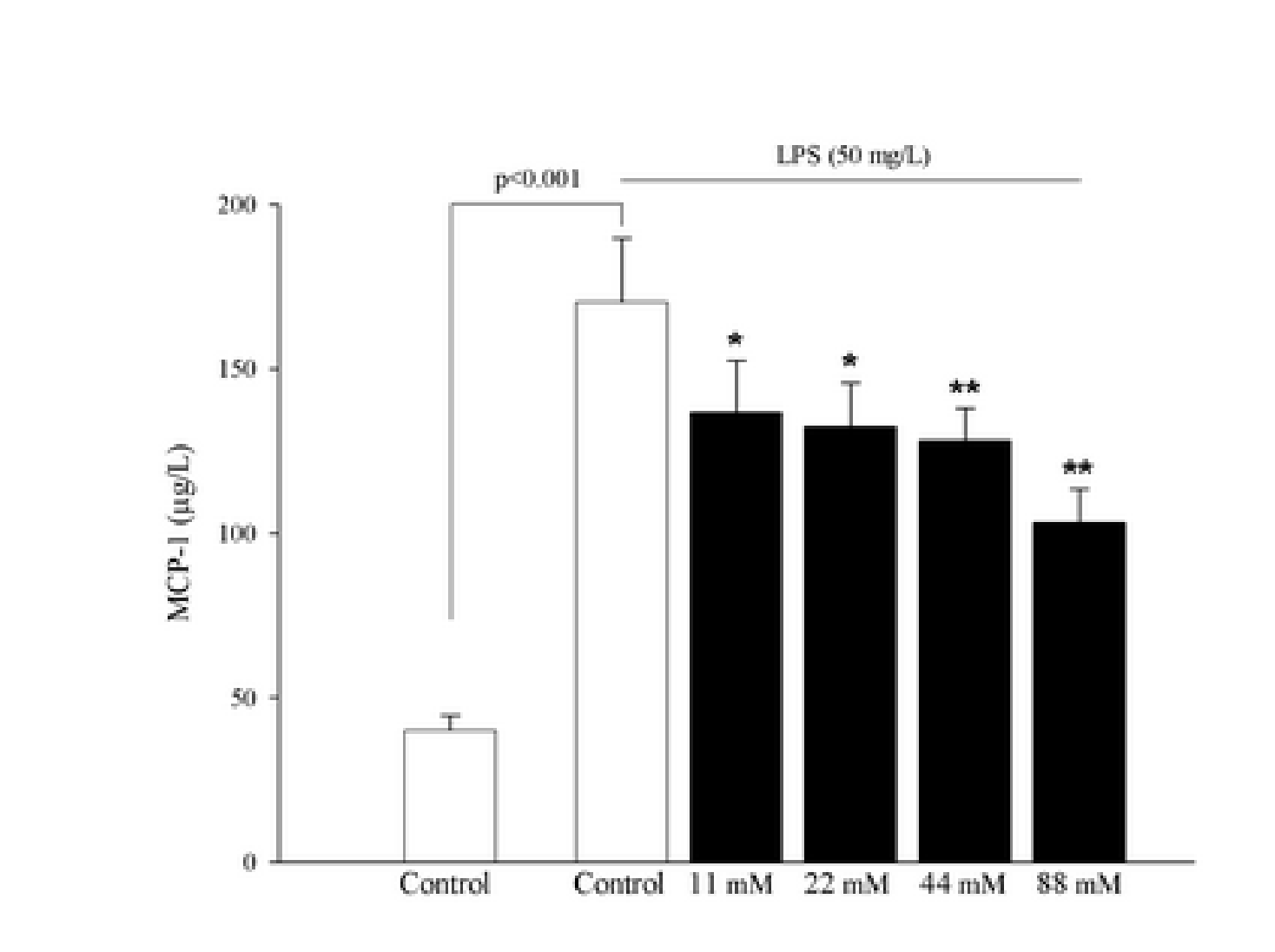

m

更 